\section{Geochemical Evolution and}

\section{Distribution of Ore Deposits in the Morava Massif During the Pre- Mesozoic Time}

Popović, R.*

Miljković, Lj.**

\section{Abstract}

The formerly distinguished Serbian-

Macedonian Massif has been divided by Popović (1990b and 1991) in to two geotectonical blocks: the Pelagonian-Rhodopean and the Morava massifs. The second one, including the Green and the Gneiss complexes, mostly occurs in Serbia. It is supposed that the first block originated in the oceanic area during the Baikalian stage (this opinion being supportedbypaleontologicalrecords), whereas the gneisses are assumed to originate in the continental crust, during the same stage of the Baikalian tectonic-magmatic cycle. The Baikalian matallogenic epoch in the green complexisfeatured by the $\mathrm{Fe}$, $\mathrm{Ti}, \mathrm{S}, \mathrm{Cu}, \mathrm{Cr}, \mathrm{Zn}$ and Au occurrences, beingparticularlycharacterizedbycopper sulfides and gold. It is supposed that two constituents could play an important role in the future investigations.

It has been presumed that this metallogenic epoch is related to the small iron deposits (Žitni Potok, Desivojce, Sedlare, Car and other), which appear in the gneiss complex. The Calledonian metallogenic epoch is especially characterized by copper sulfides, graphite occurrences and phosphate deposits, as well as by the iron deposits of the silicate-carbonate type and also by the manganese, nickel and cobalt occurrences. Finally, the Hercynian metallogenic epoch is known by thecontinental regimeproducingthecoal and uranium deposits in sediments and granitoids, as well as the beryllium occurrences in pegmatites.

Key words: Morava Massif, Geochemical, evolution,Baikalian,Caledonian,Hercynian, epoch, Green complex, Gneiss complex. * Radule Popović, "Geoinstitut", YU, Beo-
grad, Rovinjska 12

**LjupčeMiljković,InstituteofGeography, University of NoviSad, YU, NoviSad, Trg Dositeja Obradovića 3
T he metallogenic studies of the central and southern parts of Balkan Peninsula yielded very intresting data, indicating the fact that the preMesozoic geochemical and metallogenic evolution of the southern part was different than at of the central part. These differences were brought to a focus by data about the age of individual lithological complexes, various geotectonical settings of their origin, and diverse metallogeny. According to these data in the Serbo-Macedonian mass, two parts are distinguished: Pelagonian-Rhodopean massif and Morava massif (Popović, 1989, 1990a, 1990b, 1991, 1992a, 1992b, 1993a).

Since the evolution of these massifs in the pre-Mesozoic time is not the same, every of them has its various and specific metallogenic and geochemical evolution. In the post-Paleozoic epoch, they exhibit the common geochemical, metallogenic, geotectonic and tectonic development.

\section{Geotectonic Setting and Generating of the Morava Massif}

The Morava massif represents a geotectonic block composed of two metamorphic complexes: Gneiss and Green ones. In the older literature, especially in Booklets of Basic Geologic Map for sheets covering the Morava massif, the Gneiss complex is considered as the lower unit, compared with the overlying Green of (or) Vlasina complex respectively. On the basis of newer informations (Popović, 1989, 1990a, 1990b, 1991, 1992a, 1992b, 1993a, 1993b), it is considered that both of these complexes originated in various geological settings.

According to incomplete investigations of Vasković (1984), amphibolites occurring in the gneiss complex could represent products of basic magmatism of the tholeiitic series, but exhibiting varied controversial geochemical features. After that author, these amphibolites would vary from oceanic tholeiites, via island arcs to tholeiites of continental rifts, noting that the microelement contents exclude oceanic origin of these rocks. Vasković (1984) has supposed that they were formed in both "island arcs and continental rifts". However, the other geochemical and metallogenic characteristics of island arcs being absent, it could be considered that the mentioned tholeiites were created in the area of continental rifts or continental margins, while the other rocks, were originally protolithic sediments, formed in water environment, existing in the domain of continental geotectonic setting (continental margin too).

The Green or Vlasina complex, compared with the Gneiss complex, is of rather variable features. It is known that it includes various chlorite schists, thenmetagabbros, metadiabases, metaspilites and regionally metamorphosed serpentinites (Maksimović, 1961). On the basis of these data, it is believed that the green schists were formed in the oceanic type segment of the Earth crust. These comprehensions are supported by partial petrochemical investigations of rocks from green schists (Popović, 1993a and 1993b). Here are discussed the rocks which could be considered as abyssal tholeiites or as oceanic floor tholeiites. This explanation remarkably differs from the explanation of Krstić and Karamata (1992) which consider that the so called Vranovac - Vlasina terrane was formed in the Baikalian - Caledonian time, the lower part being originated in the island arc area, and the upper part in the basin behind the island arc. The petrochemical investigations, presented at the diagram (Fig. 1), would not be in accordance with that opinion, that is why in this paper has been preserved an opinion that primary rocks of the Vlasina complex belong to abyssal tholeiites.

Such an opinion is supported by data presented at the Pearce, $\mathrm{s}$ diagrams of $\mathrm{Ti}$ and $\mathrm{Cr}$ ratio as well (Fig. 2), related to the rocks of green schists from the Vlasina (or Green) complex.

From the quoted text it could be ascertained that rocks of the Gneiss complex originated in the area of the continental type of the Earth crust (continental rift, continental margin), and the green schists were formed in the segment of the oceanic type Earth crust, 

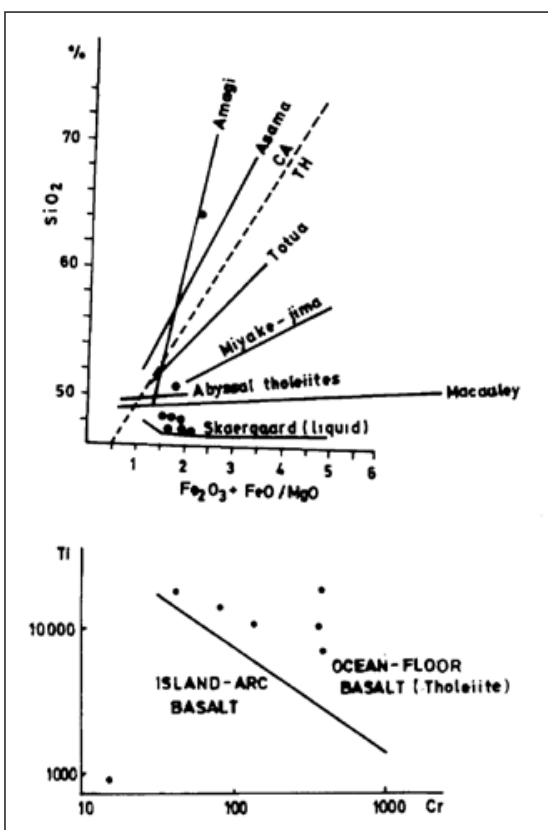

Fig. 1. Position of green schists of the Vlasnina complex on Miyashiro's ram for green (1975) diagram $\mathrm{SiO}_{2}$ versus $\mathrm{FeO}(\mathrm{t}) /$ $\mathrm{MgO}$; Fig. 2. Ti versus $\mathrm{Cr}$ diag- schists of the Vlasina complex

both of them representing the separate geotectonical settings.

\section{Age and Mutual Relations of the Gneiss and Green \\ Complexes}

Judging from the available informations it can be considered that the oldest rocks of the Gneiss and Green complexes of the Morava massif originated during the Upper Proterozoic- Lower Paleozoic time. This is pointed out by paleopalynologyand otherpaleontological records of Pantić et al (1974) and Pantić (1975) collected near Lebane (Acanthotriletes cf. spinelosus Naum., Fusumorphidae gen. et. sp. indet, Protoleiospheridium sp. and others), and Kalenić et al (1974) gathered at Resava Hills (Archaeofavosina simplex Naum., Protoleiosphaeridium sigilarium Andreeva etc), but also by records of Pantić and Dimitrijević (1966) related to a part if crystalline basement in the Vlasnina district (Protoleiosphaeridium conglutinatum, Acantholigotriletum carelense Tim etc). Further on Kalenić (1966) established the Lower Cambrian age rocks near Crnajka (eastern Serbia) and Pavlović (1964) proved Ordovician age (based on Orbiculoidea sodalis Barr. and differents Obolus howkei Dav and others) nearby Bosilegrad. Pantić et al (1967) found evidence for the Riphean - Cambrian (Trachyoligotriletum magnum Tim., Stenozonoligotriletum sokolovi Tim etc) in the Vlasina river basin, and Kalenić et al (1974) found floral proofs for the same, Riphean - Cambrian age in the Resava Hills - Botunje village cross section.

Dimitrijević (1963) and Dimitrijević, and Ćirić (1965) discussed an information about the Cambrian - Ordovician age of some metagranitoids from Kukavica (Vlajna) based upon isotopic studies, and Deleon et al (1970/72) determined $\left(\mathrm{Rb}^{87} / \mathrm{Sr}^{86}\right)$ the Cambrian - Devonian age (up to 500 M.y.) of crystalline schists in the Južna Morava and Velika Morava river valleys. But in the last several years reported by Balogh et al (1994) that the primary sediments of the gneiss complex near Batočina originated about 488 to $700 \mathrm{My}$ ago $\left(\mathrm{Rb}^{87} / \mathrm{Sr}^{86}\right)$. At any rate, both Gneiss and Green complexes originated, according to available data, during the Baikalian and Caledonian tectonomagmatic cycle. The both complexes contemporaneously originated in two various geotectonical settings, the continental part with the Gneiss complex from one side, and the oceanic part with the Green complex from the other side. Both of these areas seem to be relatively close. With regard to their lithological composition, one could suppose that during the later evolution they were "compressed" (collided).

If we have looked at the present day for traces of such an activity, it could be recognized in the Vrvi Kobila structure which in that case could exist as a rudiment of the mentioned geotectonical activity. It involves the basic magmatism, existing as remnants in the Gneiss complex, and which could be related to the island arc, as was given hint by Vasković (1984), either are the active continental margin or continental rift in question.

The mentioned tectonic activity could already start near the end of Baikalian or could be finished in Hercynian tectnomagmatic cycle.

In the Morava massif accordingly, in the pre-Mesozoic time, the Baikalian, Caledonian* and Hercynian metallogenic epochs could be distinguished.

\section{Baikalian \\ Metallogenic Epoc}

The Morava massif is composed oftwogeotectonicblocks originated in various geotectonical settings, thus their geochemical and metallogenical features are to be separately presented.

\section{A. Green (Vlasina) complex}

As judged by age studies to date it could reliably be asserted that the green schists of the Vlasina complex, as well as the Gneiss complex originated during Upper Proterozoic time.

Since the Green complex was generated in an oceanic area (probably the area of ocean floor or ocean ridge), its formation was accompanied by the corresponding metallogeny. Accompanied by the magnetite, titanomagnetite and subordinated sulfide mineralizations. The magnetite and titanomagnetite mineralizations always occur as impregnation, locally as lenses of ferruginous quartzites. They appear in the whole area covered by green schists, from Dobra at

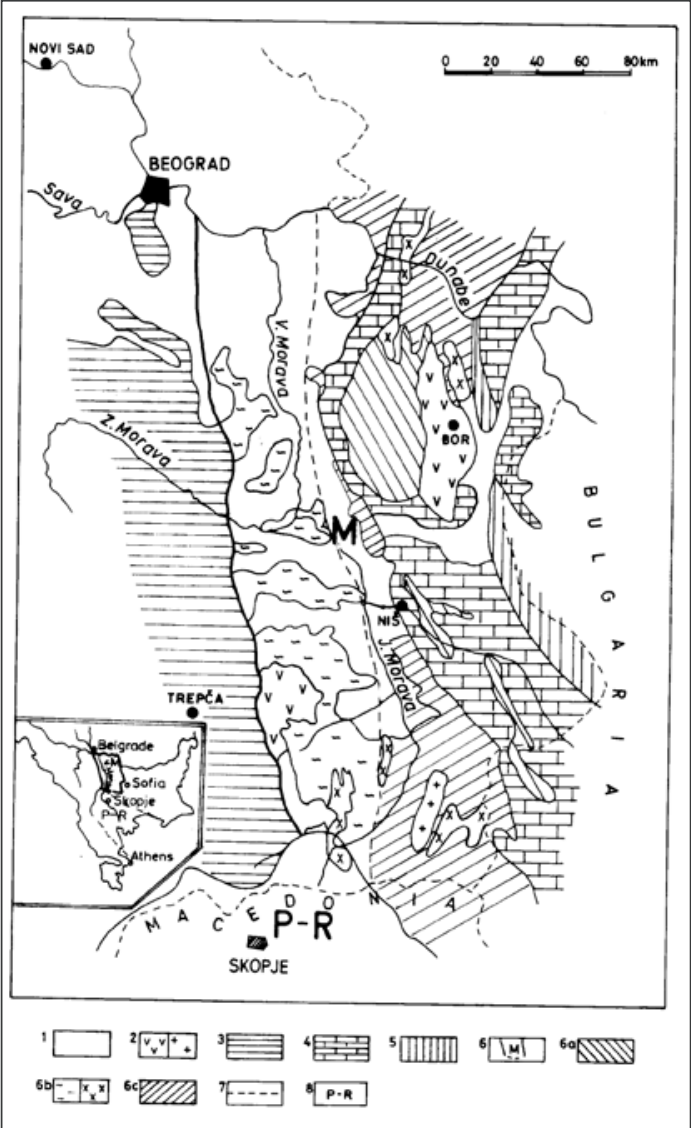

Fig.3.Simplified Geologic Map of the Morava Massif. 1.QuternaryandTertiarysediments,2.EffusiveandintrusivemagmaticrocksofTertiaryage,3.Ophiolitesof theVardarzone-Mesozoic andTertiarysedimentary andmagmaticformations,4.Mesozoicsedimentaryand magmaticformations ofeasternSerbia,5.Formations of the Stara Planina block, 6. Morava Massif, 6a. PhyllitoidsofeasternSerbia,6b.Gneissandmetagranitoids -UpperProterozoicand the LowerPaleozoic, (Gneiss complex),6c.Chloriteschists,metadiabases,metagabbroids,regionalmetamorphosedserpentinites(Green complex), 7.VrviKobilazone(Borderbetween Gneiss andtheGreencomplexesoftheMoravaMassif),8.Pelagonian-Rhodopean Massif. 


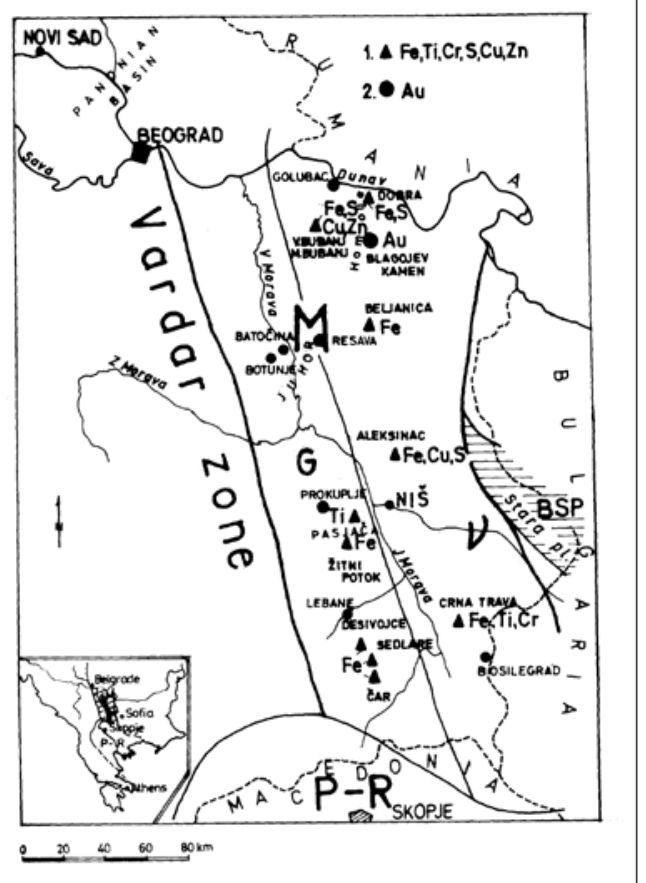

Fig. 4. Simplified map of occurrences of Baikalian metallogenicepochintheMoravaMassif(afterPopović, 1996).

M-Morava Massif,G-Gneisscomplex, V-Greencomplex, P-R: Pelagonian-Rhodopean Massif.

Danube, via Beljanica, along the Morava zone, via Crna Trava, and further to the Southeast. In these mineralizations, the most abundant magnetite, then ilmenite, rutile, titanomagnetite, and seldom hematite were found. These are, however, of meagre economic importance, the magnetite concentrations in most of occurrences being less than $5 \%$. As implied by Foot, cited by Janković (1990), here the chlorite schists with magnetite impregnations are in question, including lenses of ferruginous quartzites of various sizes. The ferruginous quartzites with magnetite impregnations exhibit the iron contents varying about $20 \%$, with ore reserves estimated at over 10 million tons. In these mineralizations, magnetite and hematite are the chief ore minerals, locally accompanied by pyrite and chalcopyrite.

Beside the mentioned iron mineralizations, in the Bukovik and Rožanj (near Aleksinac) green schists the spherosiderite occurrences of subordinated importance were also found.

When discussed titanium, it is essentially characterized by mineralizations with ilmenite and rutile as leading minerals. In respect to this fact, after Vujanović and Teofilović (1980), the most important occurrences appear in green schists of Crna Trava, exhibiting $\mathrm{TiO}_{2}$ contents grading to $10 \%$. For the time being none of the known occurrences could be considered to be of economic importance.
As far as the origin is concerned, it is considered that this is a volcanic-sedimentary formation, later metamodphosed into the facies of green schist.

This complex is characterized by occurrences of weak chromium mineralizations, related to the regionally metamorphosed serpentinites. After Vujanović et al (1980) in the Crna Trava area they include chromite, chromspinel and $\mathrm{Cr}$ magnetite as the chief ore minerals, but in the paragenesis sporadically occur other minerals, such as magnetite, pyrite, chalcopyrite, rutile, etc. The chromium grades are extremely low, seldom reaching 0,5\%, these mineralizations thus havingonlygeneticalandgeochemical importance.

Beside the Crna Trava locality, chromium and nickel occurrences are registered in northeaster Serbia, also related to the regionally metamorphosed serpentinite (Kalenić et al, 1973). This occurrence is not of economic importance, but it is, along with the previously described one, important for deciphering the petrogenetical and geotectonical environment of their formation.

Green schists of the Morava massif particularly are characterized by occurrences of important sulfide concentrations. Neglecting the traces of these mineralizations largely occurring in a considerable area around Homolje, Beljanica, Crna Trava and elsewhere, but relying only on important concentrations, it is remarkable that during formation of this complex, beside all other geochemical features, sulfur is one of such chemical elements which could be said to be one of the main geochemical characteristics of this complex. As a proof for such a comprehension may serve the prominent sulfide deposits occurring near Golubac, Veliki Bubanj, Mali Bubanj nearby Petrovac-on-Mlava, then at Bukovik and Rožanj near Aleksinac. It is certain in most of cases that pyrite is in question, while concentrations of other sulfides, except the copper sulfides, are sporadic. The copper concentrations in some localities could indicate an important potentiality of this complex concerning the copper deposits.

In sulfide mineralizations of Veliki Bubanj and Mali Bubanj the most abundant is pyrite (over $90 \%$ of all ore minerals), while the other, such as pyrrhotite, marcasite, chalcopyrite, and sphalerite are quite subordinated. Beside these, in this mineralizations the siderite, minnesotaite, hematite, hydrohematite and especially abundant limonite were found. This last mineral originated by intensive sulfide weathering, forming a large iron hat (gossan).

Anyway, the chalcopyrite enrichments in the Veliki Bubanj and Mali Bubanj localities would not be completely neglected, although this mineral is present in relatively limited amounts. According to Buković et al (1977) the copper contents up to $0.4 \%$ were locally found, while the zinc grades are up to $0.6 \%$. The same author considers them as the volcanogenic-sedimentary type of mineralizations.

The occurrences of similar composition, genesis, general feature, and sulfide concentrations appear near Golubac as well. However, the most important mineralizations of this type occur at Bukovik and Rožanj near Aleksinac. As reported by Buković, cited by Janković (1990), beside the remarkable pyrite concentrations, the prominent copper occurrences are present here as well. Until recently more than 10 occurrences in both localities are registered. In question is mostly impregnation type with local veinlets, often giving impression of a stockwork-impregnation general feature. This mineralizations was followed to nearly $200 \mathrm{~m}$ depth, obviously indicating a voluminous sulfide mineralization. The copper contents vary in this assemblage from 0.02 up to $0.12 \%$, in which are incorporated some individual segments of several meters in (illusory) thickness, with copper grades from $0.25 \%$ up to $0.44 \%$. The ore paragenesis includes pyrite, chalcopyrite, pyrrhotite, bornite, tetrahedrite, marcasite, magnetite and hematite.

Such large sulfide concentrations in the Green complex of the Morava massif strictly distinguished these green schists from the similar schists in western Serbia or in the Pelagonian-Rhodopean massif.

Finally, if data of Kalenić et al (1973) and Bugarin (1994) would be taken into account, the most important feature of this complexwould be the gold and tungsten occurrences near Blagojev Kamen and some other localities as well. The mentioned authors consider, when gold is in question, that it was syngenetically generated with the protolith of green schists and that they were formed mostly by volcanogenic-sedimentary processes. If this comprehension would be proved, the potentiality of the Green complex could be considerably increased. 
From the over mentioned information it is evident that the geochemical association of chemical elements exhibits $\mathrm{Fe}, \mathrm{S}, \mathrm{Zn}, \mathrm{Cu}, \mathrm{Ti}, \mathrm{Cr}$ and $\mathrm{Au}$ as essential elements (Fig.4). It is evident that these elements derive neither from the same petrogenetical environment nor from the same level, and are not of the same age, although they were formed in the Baikalian tectonomagmatic cycle. As implied by Aleksić and Kalenić (1981) at the time of the Baikalian tectonomagmatic cycle an eugeosynclinale zone was developed at the margin of the old Baikalian land. But said Janković (1990, p. 87): "Although there are not sufficient data for a competent conclusion, a part of these magmatic complexes is most probably related to the intracontinental rifting, which could later lead by further spreading to organizing and formation of oceanic crust with ophiolitic complexes, as it occurred in a similar way in the initial stages of the young Alpine cycle". Accordingly, the comprehensions of the mentioned author, the association of chemical elements, petrologic composition, as well as the other previously presented proofs, speak in favour of an oceanic geotectonical setting responsible for generation of green schists and the related mineralizations.

\section{B. Gneiss complex}

The gneiss complex extends west of the Green or Vlasina complex respectively. In the southern part they are separated by the prominent Vrvi Kobila tectonic zone, which probably represents the mutual separation of these two complexes along the total length of their contact. From the western side, the Gneiss complex is bordered by the Vardar zone, southerly it is limited by the PelagonianRhodopean massif, while to the north it sinks beneath the Tertiary deposits of the Panonian basin.

The Gneiss complex is mostly composed of gneisses, micaschists, quartzites, which are supposed to originate from both sedimentary rocks as their protoliths and amphibolites, the basic magmatic rocks being their protoliths. It has been established by investigations that at numerous localities the preserved relics of primary gabbroid and diabase rocks are present; that is why it is a vindicatory opinion that this complex originated to a great extent by volcanogenic-sedimentary activity, partly followed by plutonic rocks.

In contrast to the Green complex, in which the substantial (paleontological) evidences about Baikalian age (Upper Proterozoic-Cambrian respectively) were found, in the Gneiss com- plex such evidences until now have not been found. After Dimitrijević (1963), Dimitrijević and Ćirić (1965) the earlier Paleozoic for the Vlajna granitoid has been presumed, according to the zircon (U-Pb) absolute age. Regretfully, this record is highly questionable, because the age of zircon is not always of the same age as the rock itself. Until now, we have records for the Devonian paleontological age for crystalline rocks near Lebane (Pantić et al, 1974), which could be considered as the only more or less reliable datum about the age of the Gneiss complex. Deleon et al (1970) determined, regarding isotope $\left(\mathrm{Rb}^{87} / \mathrm{Sr}^{86}\right)$ investigations, the Cambrian-Silurian age of muscovite from crystalline schists of Juhor.

Proceedings from numerous geological data, mutual relations of individual lithological units, and extrapolation of the age records of individual rocks, speak in favour of the Upper Proterozoic-Lower Paleozoic age of the Gneiss complex.

With regard to different geotectonical settings generating both Green and Gneiss complexes, and to their various lithological composition, it is clear that thecorresponding metallogenyand geochemistry of ore deposits would be different.

The most important metallogenic and geochemical features of this complex are small iron deposits at Pasjača, near Žitni Potok, Sedlare, Čar, and northeasterly from Vranje, as well as the magnetite and titanomagnetite impregnations in amphibolites distributed in the Gneiss complex as smoller or larger lens-like bodies. All mentioned deposits and occurrences are mostly of stratiform general feature, related to amphibolites, quartzites and gneisses. These deposits have been more detailed described by Pavlović (1952), Simić et al (1959) and Janković (1990).

It is interesting that most of these deposits also exhibits high phosphorus grades, locally reaching even over $4 \%$, as it is the case near Desivojci. These are, as a whole, small ore bodies, which total less than 500 thousand tons of ore. Magnetite impregnations with or without titanium contrary show the considerable ore reservs estimated to total sveral tens of million tons, but averaging less than $18 \%$ iron.

Some of these deposits underwent not only regional but the contact metamorphism too, resulted in later recrystallization and enrichment in various minerals, especially in pyrite, and subordinated chalcopyrite, sphalerite and galena. This contact metamorphism was caused by intrusion of younger granitoids, exposed at many localities.

Titanium is the other chemical element forming ore occurrences in the Gneiss complex, represented by such minerals as ilmenite, ilmenohematite, sphene, rutile and titanomagnetite. These mineralizations are almost completely restricted to amphibolites. As reported by Vujanović and Teofilović (1980), contents of this element are very variable, most commonly grading around $4 \% \mathrm{TiO}_{2}$, more seldom over $5 \%$, and sporadically over $6 \% \mathrm{TiO}_{2}$. The main occurrences appear at Jastrebac and Pasjača.

It could be concluded that the Gneiss complex of this epoch is characterized by iron and titanium.

\section{Caledonian Metallogenic Epoch}

According to knowledges until recently the metallogenic and geochemical evolution continued from the Baikalian to the Caledonian epoch; in that occasion the evolution of geotectonical setting enrolled in the direction of transformation of the oceanic type of the Earth crust into the continental type.Namely, to the end of the Baikalian tectonomagmatic cycle began uplift of the Earth crust, so that a part of the oceanic district of eastern Serbia was transformed during Caledonian epoch into land, causing the regime of further geochemical evolution which characterized such a geochemical environment.

The most important metallogenic and geochemical characteristics of this epoch are the phosphorous and iron deposits, then graphite occurrences, and as implied by Babović et al (1977), cobalt and nickel occurrences.

As far as concerned phosphates, near Lisina in SE Serbia is known a deposit with reserves estimated to reach over 40 million tons with $\mathrm{P}_{2} \mathrm{O}_{5}$ grades less then 15\% (Janković, 1990). This deposit is sedimentary in origin, having undergone the post-ore regional and partly contact metamorphism.

As far as concerned iron, this epoch is characterized by occurrences of the silicate-carbonate-oxide ore or so-called chamosite ore. Such an ore deposit is known in Ordovician semimetamorphites of Kučaj. It is of volcanogenicsedimentary origin and is genetically directly restricted to the diabase-spilite volcanism. The most important ore minerals are Fe-chlorites (of the chamosite group) and siderite, while magnetite and hematite are subordinated. The iron content in these ores is low, seldom 


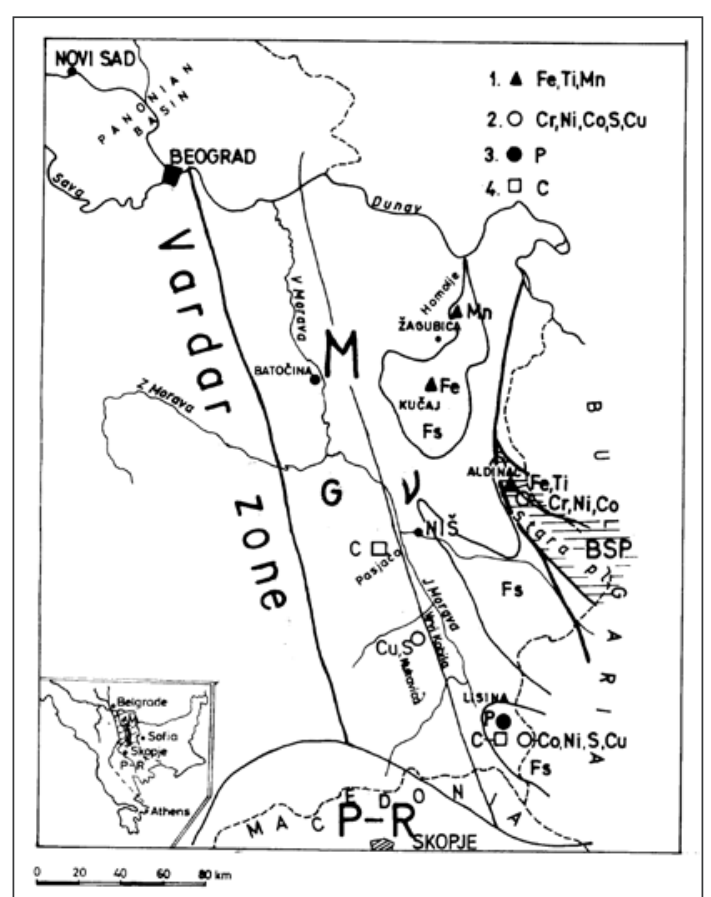

Fig.5.SimplifiedmapoforeoccurrencesofCaledonian metallogenicepochintheMoravaMassif(afterPopović, 1996).

M-MoravaMassif,Fs-Phyllitoidcomplex(Caledonian cycle), G-Gneisscomplex(Baikalian-Caledoniancycle), V-Greencomplex (Baikaliancycle), SP-StaraPlanina block, P-R: Pelagonian-Rhodopean Massif.

reaching $25 \%$. The ore reserves are estimated to be more voluminous than 10 million tons.

Graphite occurs as an important geochemical feature of this epoch, being registered at several places forming graphite schists with considerable local concentrations. As shown by Babović et al (1977), the carbon contents in the graphite occurrences in the Lisina series (southeastern Serbia) reach $40 \%$. The same authors have reported in the same district the sulfide mineralizations exhibiting cobalt and nickel as the chief geochemical feature. Near Bresnica, nearby the Bulgarian frontier, in such an occurrence appear pyrite, pyrrhotite, pentlandite, chalcopyrite, sphalerite, bravoite, graphite, ilmenite and other Ti-minerals. For that occurrence they have reported the thickness varying from 1 up to $15 \mathrm{~m}$, being traced for $300 \mathrm{~m}$ in length. Other data about this occurrences are not available.

Regarding information of Milošaković and others, cited by Janković (1990), in Ordovician units of Homolje the manganese occurrences are present, related to the volcanogenic-sedimentary activity, genetically related to keratophyres. This mineralizations is characterized by the high content of silica, locally being leached, producing the manganese hats with the overconcentrated $\mathrm{MnO}_{2}$ usually grading less than $20 \%$, but also exhibiting over $20 \% \mathrm{MnO}_{2}$.
The other part of the Morava massif, occurring west of the Vrvi Kobila tectonic zone, could be considered absolutely nonproductive either in metallogenic or geochemical sense. Except the weak sulfide mineralization at Kukavica and graphite occurrences at Pasjača, other mineralizations are not known. The pyrite mineralization at Kukavica exhibits copper content of $0.20 \%$, until the lead and zinc grades are negligeable (less than 500 $g / t)$.

Accordingly, the Caledonian metallogenic epoch in the Morava massif is characterized by appearance of $\mathrm{Fe}, \mathrm{C}, \mathrm{S}, \mathrm{Mn}$, $\mathrm{Ni}, \mathrm{Co}$, and $\mathrm{Cu}$ (Fig 5). Such an association of chemical elements, which took place in ore deposits and occurrences, strictly difers from the Pelagonian-Rhodopean massif. Difference between the Green and Gneiss complexes is also clearly remarkable.

There are some opinions that to this metallogeny the gold occurrences could be related, but it is more probable that the younger mineralizations are in question. In that regard the data of Andjelković et al (1969), consider both auriferous quartz veins with lead, zinc, copper and silver, also barite veins, to be related to the Caledonian epoch, Krstić et al (1970) think also that the chromium, ilmenite, magnetite and gold occurrences near Aldinac and at Stara Planina generated in the Caledonian metallogenic epoch. According to available data, it is hard to accept such a possibility, as the veins cut formations generated in Caledonian epoch, and such an elements association is not characteristic for the Caledonian epoch of the Morava massif as well. It could be more certain to consider them as epigenetic mineralizations originated in younger metallogenic epochs.

\section{Hercynian Metallogenic Epoch}

When discussed the Morava massif and its eastern trending, there arose a serious problem. It is, namely, evident that it partially also prolongates to Bulgaria, but it is very questionable if it is restricted or not to the Stara Planina district. In that regard the position of uranium metallogeny is very doubtful. As far as concerned the question of uranium origin in granitoids of Stara Planina a sat- isfactory answer is hardly to be found. It is less certain that the oceanic type of the Earth crust, which existed in the Morava massif (Green complex), could be the source of uranium. Until recently no traces of uranium have been found in the Green complex. But, this is a problem which remains open for the time being, so that disregarding to this question, thecorrespondingmetallogenic and geochemical features of Stara Planina, as a separate block will be presented here, since it geographically corresponds to eastern Serbia, and during Mesozoic and Tertiary time it was restricted to the same metallogenic region.

The uplift of the Morava massif, which began near the end of the Baikalian tectonomagmatic cycle, continued, according to data of Krstić and Karamata (1992) throughout the Caledonian tectonomagmatic cycle, indicating at this time presence of land or continental environment respectively, so that in the Hercynian time in a large area of eastern Serbia a continental geotectonical setting existed. All of these processes were accompanied by corresponding magmatismandmetallogeny, generating the granitoid massifs with uranium. In the surrounding aquatic basins uranium was precipitated from the eroded and redeposited granitoid material in the late phases of the Hercynian epoch. In the same Carboniferous time, the flora was developed, producing later the hard coals (subantracite)

Bearing in mind the uranium occurrences in the Stara Planina granitoids and in Carboniferous and Permian sediments, then the appearance of hard coal in sedimentary rocks, as well as the continental geotectonical setting, it may be ascertained that those are the most important features of the Hercynian metallogenic epoch in the Morava massif. Concerning these properties it distinctly differs from all previous metallogenic epochs.

Judging from the records of Deleon (1969), the oldest granitoid rocks of Stara Planina originated during Hercynian tectonomagmatic cycle. Antonović (1973) has considered, however, that (Janja) granitoids are much older (preOrdovician), similarly as implied by Gertik (1976) who defined them as Caledonian in age. These opinions have been accepted by Andjelković et al (1977), Krstić et al (1977) and Krstić and Karamata (1992).

Uranium in Stara Planina had been explored during a longer period. According to information of Gertik (1976) and some other authors (their reports being 
presented in the funds of the non-published investigation reports) it is evident that the Stara Planina granitoids (mostly the Janja massif) are remarkably enriched by uranium. Unfortunately, from the explanations to date it is seen that these mineralizations are represented by small ore bodies, the total reserves not exceeding 700 tons of uranium, averaging less than $500 \mathrm{~g} / \mathrm{t}$ of uranium, noting that until presently only 100 tons of uranium has been found in the ore with the mean content of $700 \mathrm{~g} / \mathrm{t}$ of uranium. By use of newer scientific knowledges and with new scientific concepts, the new discoveries which would enlarge the uranium potentiality of Stara Planina and eastern Serbia as a whole, will be surely effectuated.

In the ore paragenesis of Stara Planina were found: pitchblende, uraninite, torbernite, uranotorianite, accompanied by numerous sulfides of copper, iron, lead, molybdenum, then by magnetite, hematite, etc.

The uranium mineralizations in metasediments and sediments are certainly younger than uranium mineralizations in the Stara Planina granitoid, generated mostly at the end of the Carboniferous and Permian time. These mineralizations occur as thin stratiform bodies, mostly of the lens-like shape. Among uranium minerals, firstly occur sooty pitchblende, autunite and torbernite. Uranium contents in sediments mostly vary between 250 and $600 \mathrm{~g} / \mathrm{t}_{i}$ the uranium reserves are estimated, after Gertik (1976, 1987, 1988, 1989) to total about 400 tons. According to some other estimations (oral communication by Jovan Kovačević, having been occupied for many years by these problems) in sediments of eastern Serbia much more voluminous reserves, than these established to data, and with uranium contents which could be of commercial value, may be expected.

As far as concerned other mineralizations, especially of sulfides, the authors of the Booklets of the Basic Geologic Map of these tracts ( Andjelkovic et al, 1969; Krstić et al, 1970, and others) supposed many of vein-like occurrences of the sulfide and other mineralizations to belong to this metallogenic epoch. However, when discussed the epigenetic mineralizations, it is more probable that they could be restricted to the you-nger tectonomagmatic events, which happened in the post-Hercynian time.

From the other side, during Hercynian metallogenic epoch in the Gneiss complex the large pegmatite deposits were formed. When the geochemical and metallogenical evolution is in question, their importance reflect beryllium occurrences, which are very characteristical for this part of the Morava massif. The beryl occurrences are registered near Prokuplje, at Kukavica and near Bujanovac. It is interesting to mention that pitchblende was for the first time found in Yugoslavia, in association with beryl near Prokuplje, as a matter of fact only as a mineralogical curiosity (Fig.6).

There are, however, opinions (Vu-kanović et al, 1970) that the tin, tungsten, and antimony occurrences belong to this epoch, but there is no proof for such a statement. It is more probably that they are related to the post-Hercynian epoch. Accordingly, if the hard coal would be taken into consideration as an ore and geochemical feature of this metallogenic epoch, it would represent, along with uranium and beryllium, the most important metallogenic and geochemical feature of the Hercynian metallogenic epoch of the Morava massif.

\section{Conclusion}

From the above presented text, it is evident that the Morava massif was developed during the Baikalian and Caledonia epochs in two different geotectonic settings, directing to a great extent the corresponding metallogenic and geochemical evolution. Iron is the leading metal constituting the ore for most of epochs, except the Hercynian metallogenic epoch in which are not present importand iron mineralisations. The same role is to be attributed to titanium. As far as concerned the Baikalian epoch, beside the mentioned metals, it is characterized by occurrences of copper, zinc and iron sulfides, what is a supporting evidence about an important geochemical feature of sulfur during formation of the Green complex.

These data show that the Green complex of the Morava massif, generated in the Baikalian tectonomagmatic cycle, represents a very important metallogenic setting. It is very likely that important iron, copper and gold concentrations are to be expected there.

In the same time in the Gneiss complex, the small iron deposits and lesser titanium concentrations were generated. These deposits exhibit less than one million tons, but with high iron grade,

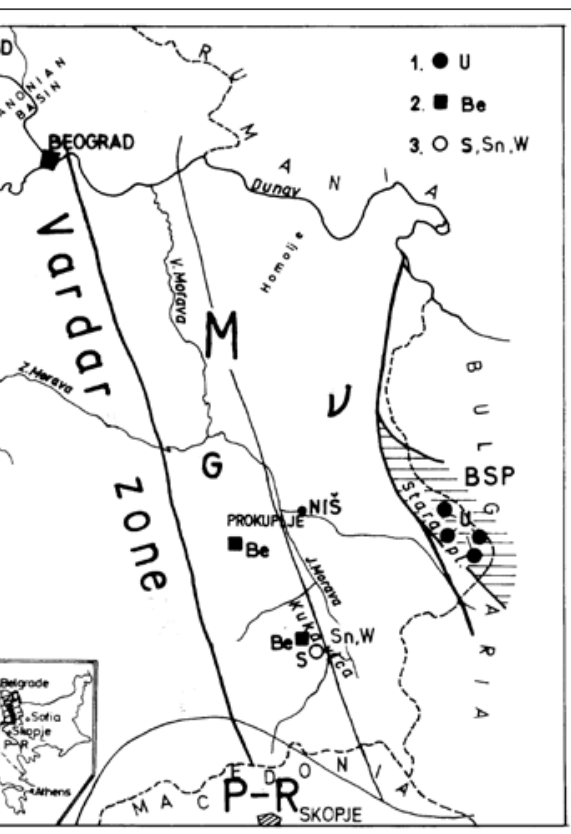

$60.50 .00 \mathrm{~m}$

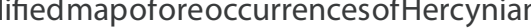
M-Morava Massif G-Gneiss complex V-Baikalian, CaledonianandHercyniancomplexes,SP-StaraPlanina P-R: Pelagonian-Rhodopean Massif.

related to magnetite.

The most important geochemical feature of the Caledonian epoch are phosphorus and carbon, as confirmed by the phosphate deposit near Bosiljgrad, as well as by smaller graphite occurrences. Finally, to this epoch the smaller or larger iron (silicate-carbonate type), manganese, nickel, cobalt, copper and sulfides occurrences are restricted.

The Gneiss complex is, accordingly, characterized, first of all, by the weak sulfide mineralizations and smaller occurrences of graphite schists, since the formations of the eastern part, stratigraphically overlapping the green schists, are featured by $\mathrm{Fe}, \mathrm{Mn}, \mathrm{S}, \mathrm{Ni}$, $\mathrm{Co}, \mathrm{Cu}, \mathrm{P}$ and $\mathrm{C}$ (Table 1).

Finally, the Hercynian metallogenic epoch is characterized by uranium deposits occurring in granitic rocks of eastern Serbia and in Permocarboniferous and Permian sediments. If beryllium and hard coal are added, the Hercynian metallogenic epoch is completely featured by uranium, beryllium and carbon.

Table 1. Geochemical evolution of ore deposits in the Morava massif

Tectonomagmatic cycle and association of metallogenuic elements in epoch ore deposits

Hercynian $\quad \mathrm{U}, \mathrm{Be}, \mathrm{C}$

Caledonian $\mathrm{Fe}, \mathrm{Mn}, \mathrm{S}, \mathrm{Cu}, \mathrm{Ni}, \mathrm{Co}, \mathrm{P}, \mathrm{C}$ Baikalian $\mathrm{Fe}, \mathrm{Mn}, \mathrm{Ti}, \mathrm{S}, \mathrm{Cu}, \mathrm{Cr}, \mathrm{Au}$ 


\section{Endnotes}

* According to Haq,s and Eisinga,s data (1987) presented in the "Geological Time Table" the formerly outline Caledonian tectonomagmatic cycle is actually divided into both Assyntic (Cambrian) and Caledonian (Silurian and Lower Devonian), ended in the Middle Devonian; in our case the Caledonian metallogenic epoch lasted from the beginning of Cambrian to the Middle Devonian age.

\section{References}

Aleksić V. , Kalenić M., 1981.: Geologija Srbije III-1 Magmatisam. Izd. Zavod za regionalnu geol. i paleontolog., Rud.-geol. fakultet, p. 293. Beograd.

Andjelković J., Krstić B., Bogdanović P., Jadranin D., Milenković R., Miloaković R., Urošević D., Dimitrijević M., Dolić D., Rakić O. M., Jovanović Lj., Maslarević Lj., Marković Lj., Marković B., Divljan M., Djordjević M., 1969.: Tumač za OGK SFRJ, listovi Pirot i Breznik. Izd. SGZ, p. 77. Beograd.

Andjelković J., Krstić B., Bogdanović P., Jadranin D., Milošaković R., Milenković P., Fotić V., i Jovanović Lj., 1977.: Tumač za OGK SFRJ, listovi Pirot i Breznik, p.67. Izd. SGZ, Beograd.

Antonović A., 1973.: Geološki odnosi $\mathrm{u}$ jednom delu Stare planine (Janja, Balta Berilovac, Ilovo).Radovi Instituta za geol.-rud. istraž. i ispit. nuk. i dr. mineral. sirovina, sv. 8, p. 1-12. Beograd.

Babović M., Roglić Č., Avramović V., Marić S., 1977.: Tumač ya OGK SFRJ, list Trgovište, p. 58. Izd. SGZ. Beograd.

Balogh Kad., Svingor E., Cvetković V., 1994: Ages and intensities of metamorphic processes in the Batočina Area, Serbomacedonian Massif. Acta mineralogica - Petrographica, v. XXXV, p. 81-94. Szeged.

Bugarin M., 1994.: Geneza ležišta zlata Blagojev Kamen, doktorska disertacija, p. 134 (daktilografisano). Rud.geol. fakultet, Beograd.

Buković J., Milošaković R., Ralević B., Timčenko V., 1977:: Izveštaj o geološko-geofizičkim istraživanjima paleozoika istočne Srbije u zajedničkom Izveštaju o kompleksnim geološko-geofizičkim istraživanjima paleozoika zapadne i istočne Srbije čiji su autori Popović R. i Buković J. i dr. Fond stručnih dokumenata Geoistituta, Beograd.

Deleon G., 1969.: Pregled rezultata odredjivanja apsolutne geološke sta- rosti granitoidnih stena Jugoslavije. Radovi Instituta za geol.-rud. istraž. nuk. i dr. mineral. sirovina, sv. 6, p. 165-182. Beograd.

Deleon G., Dromnjak M., Lovrić A., 1970.: Sroncijumova starost juhorskostalaćkog kompleksa. VII kongres geologa SFRJ, knj. II, Mineralogija i petrologija, p. 97-112. Zagreb, 1972.

Dimitrijević M., 1963.: Sur lage du metamorphisme et des plissement dans la masse serbo-macedonniene. Vle congres. de l'Ass. Geol. Carpatho-Balkanique. V.I, Stratigraphie fasc. 3. Instytut geologczny. Warszawa, 1974.

Dimitrijević M., Ćirić B., 1965.: Essai sur levolution de la masse Serbomacedonniene. Tbilisi, Geotektonika, No 5, Moskva, 1966.

Gertik S., 1976.: Geološko-ekonomska analiza stanja i mogućnost razvoja ležišta urana u granitskom kompleksu Janja - Kalna. Magistarska teza, Rud.-geol. fakultet, p. 11. (daktilografisanio). Beograd.

Gertik S., 1987.: Problemi metalogenije paleozojskih formacija Stare Planine. Radovi Geoinstituta, knj. 20, p. 33-41. Beograd.

Gertik S., 1988.: Kontrolni faktori uranskih mineralizacija u šarenim peščarima Stare Planine. Radovi Geoinstituta, knj. 22, p. 33-41. Beograd.

Gertik S., 1989.: Sedimentološko-geohemijske karakteristike šarenih peščara i kontrolni faktori uranske mineralizacije. Radovi Geoinstituta, knj. 23, p. 19-23. Beograd.

Hag B. and Eysinga F., 1987:: Geological Time Table. Elsevir Science Publishers, Amsterdam, The Netherlands.

Janković S., 1990.: Rudna ležišta Srbije. Regionalni metalogentski položaj, sredine stvaranja i tipovi ležišta. Izd. Rud.-geol. fakultet i Repub. društv. fond za geol. istraž., p. 760. Beograd.

Kalenić M., 1966.: Prvi nalazak donje kambrije u istočnoj Srbiji - južni Karpati. Zapisnici Srpskog geološkog društva za 1964, 1965, 1966, 1967, p. 591. Beograd, 1969.

Kalenić M., Hadži-Vuković M., Dolić D., Lončarević M., Rakić D., 1973.: Tumač za OGK SFRJ, list Kučevo, p. 80. Izd. SGZ, Beograd.

Kalenić M., Marković B., Pantić V., Hadži-Vuković M., 1974.: Gornji proterozoik i stariji paleozoik u profilu Resavski visovi - Batočinska Straževica - selo Botunje. Zapisnici Srpskog geološkog društva, p. 35-39. Beograd, 1975.

Krstić B., Kalenić M., Divljan M., Maslarević Lj., Djordjević M., Dolić D., Antonijević I., 1970.: Tumač za
OGK SFRJ, listova Knjaževac i Belogradčik, p. 77. Izd SGZ, Beograd.

Krstić B., Karamata S., 1992.: Terani u Karpato-balkanidima istočne Srbije. Zapisnici Srpskog geološkog društva - jubilarna sv. (1891-1991), p. 57-74. Beograd.

Maksimović Z., 1961.: Regionalno metamorfisani serpentiniti u oblasti Crne Trave (istočna Srbija). Glas SANU, Prirodno-matematičko odelenje, sv. 21, p. 7-35. Beograd.

Miyashiro A., 1975.: Classification characteristics, and origin of ophiolites. The journal of geology, v. 83, No 2, p. 249-282. Chicago. USA.

Pantić N., Dimitrijević M., 1966.: Beleška o nalsku mikroflore rifejsko-kambrijumskog kompleksa u oblasti Vlasine. Zapisnici Srpskog geološkog društva za 1964, 1965, 1966, 1967, p. 593-595. Beograd.

Pantić N., Dimtrijević M., Ercegovac M., 1967.: Mikrofloristički podaci o starosti vlasinskog kompleksa. Zapisnici Srpskog geološkog društva za 1964, 1965, 1066, 1967, p. 717-720. Beograd.

Pantić N., Ercegovac M., Aleksić V., Kalenić M., 1974.: Prethodni rezultati o nalasku staropaleozojskih spora u grafitičnim škriljcima Rujkovca (zapadno od Lebana). Zapisnici Srpskog geološkog društva za 1974, p. 41-42. Beograd, 1975.

Pantić N., 1975.:Značaj paleontoloških proučavanja starosti metamorfita u centralnoj i jugoistočnoj Evropi. Acta geologica, Prirodoslovna istraživanja, 4, p. 441-451. Zagreb.

Pavlović S., 1952. Kartiranje i istraživanje kristalastih terena i gvozdenih ruda u oblasti Prokuplja (Žitni Potok). Glasnik SANU, knj. IV, sv. 2, p.270272. Beograd.

Pavlović P., 1964.: O paralelizaciji bosiljgradskog i srednječeškog tremadoka. Zapisnici Srpskog geološkog društva za 1964, 1965, 1966, 1967, p. 225-231. Beograd.

Pearce J. A., 1975.: Basalt geochemistry used to investigate past tectonic environments Cyprus. Tectonophisics

Popović R., 1989.: Sulfide mienarlization of Caledonian epoch in southern part of Balkan Peninsula. 28th IGC, Abstract, v. 2 of 3, p. $2.625-2.626$. Washington D.C. USA.

Popović R., 1990a.: Sulfide mineralizations of Caledonian epoch in the southern part of Balkan Peninsula. Regional metamorphism of ore deposits and genetic implication. Proceedings of 28th IGC, p. 161-170. Eds. P.G. Spry and Bryndzia. VSP, Utrecht, The Netherledns, Tokzo, Japan. 
Popović R., 199b.: Srpsko-makledonska masa - da ili ne; Zapisnici Srpskog geološkog društva za 1990. Beograd.

Popović R., 1991.: Srpsko-makedonska masa ili pelagonbsko_rodopski i moravski masiv. Radovi Geoinstituta, knj. 25, p. 7-20. Beograd.

Popović R., 1992a.: Prealpine metallogenic and geochemical evolution of the ore deposits in southern part of Yugoslavia. 29th IGC, Abstracts, v. 3 of 3, p. 757. Kyoto, Japan.

Popović R., 1992b.: Rezultati ispitivanja jezgra hidrogeološke bušotine VG-3 u Vranjskoj Banji. Radovi Geoinstituta, kn. 27, p. 223-227. Beograd.

Popović R., 1993a.: Litostratigrafski odnosi u moravskom masivu na osnovu rezultata bušotine VG-3 izbušene u Vranjskoj Banji 1990/1991. god. Ra- dovi Geoinstituta, knj. 28, p. 27-34. Beograd.

Popović R., 1993b.: Geochemical and metallogenic evolution of ore mineralizations in southern part of Balkan Peninsula in Prealpine age. Proceedings of the 29th IGC, Mineral Resource Symposia. V.A. Resource Geology special issue, No 15, p. 331-341. Published of the Society of Resource, Tokyo, Japan.

Popović R., 1995.: Geohemijska i metalogenetska evolucija moravskog masiva u premezozojskom vremenu. Radovi Geoinstituta, knj. 31, p.267-284. Beograd.

Simić V.V., Vuković Ž.M. i Rakić D.S., 1959.: Rudišta magnetita na području Čar - Sedlare - Desivojce. Vesnik Zavoda za geološka i geofizička is- traživanja N.R. Srbije, knj. XVII, p.140-154. Beograd.

Vasković N., 1984.: Prilog poznavanju ortoamfibolita Končuljske klisure. Radovi Geoinstituta, knj. 17, p. 117-132. Beograd.

Vujanović V., Divljan S., Đebić V., 1980. Parageneze hroma, titana i sulfida $u$ lokalnosti Velmište (Crna Trava) sa petrologijom terena. Radovi Geoinstituta, knj. 14, p. 67-79. Beograd.

Vujanović V., Teofilović M., 1980.: Studija o titanu i pratećim metalima u srpsko-makedonskoj masi Srbije. Posebna izdanja Instituta za bakar, v. 16, br. 24, p. 86. Bor.

Vukanović M., Dimitrijević M., Dimitrijević N.M., Karjičić Lj., Rakić O.M., 1970.: Tumač za OGJK SFRJ, list Vranje, p. 58. Izd. SGZ, Beograd. 